\section{Using Crop Rotation to Control Meloidogyne hapla Chitwood and Improve Marketable Carrot Yield}

\author{
G. Bélair ${ }^{1}$ \\ Horticulture Research and Development Center, 430 Gouin Boulevard, Saint- \\ Jean-sur-Richelieu, Quebec J3B 3E6, Canada
}

L.E. Parent ${ }^{2}$

Soil Science Department, Laval University, Quebec G1K 7P4, Canada

Additional index words. northern root-knot nematode, carrot, onion, barley

\begin{abstract}
The influence of various crop rotations on population densities of Meloidogyne hapla, the northern root-knot nematode, and subsequent carrot yields was studied in organic soil under field conditions. Seven 3-year sequences with barley (Hordeum vulgare L.), carrot (Daucus carota L.), onion (Allium cepa L.), or weedy fallow, all with carrot as the third-year crop, were replicated six times in a completely randomized block design. Carrot monoculture, two seasons of weedy fallow, or carrot followed by onion resulted in high M. hapla population densities and severe root damage on carrot the third year. Barley followed by onion or onion followed by barley harbored low $M$. hapla population densities and provided the highest yields, with 56.8 and $47.2 \mathrm{t}$ marketable carrots/ha, respectively,

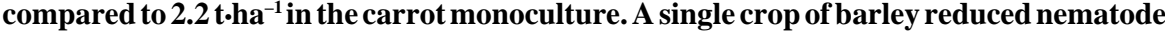
population densities and provided $88 \%$ and $73 \%$ marketable carrot roots in the subsequent years. High M. hapla population densities and the high proportion of culls recorded in plots in weed fallow emphasize the importance of an effective weed management program for successfully using crop rotation against root-knot nematode in muck-grown carrot.
\end{abstract}

The northern root-knot nematode, Meloidogyne hapla, is a major pest of carrots in the northern United States and in eastern Canada (Berney and Bird, 1992; Vrain, 1978). The infective second-stage juveniles disrupt the normal formation of the taproot and induce symptoms such as galling, forking, and stunting (Vrain, 1982). In the organic soils of southwestern Quebec, Canada, carrot monoculture is a common practice, and reduction in marketable yields from root-knot nematode infection can reach $100 \%$ in heavily infested fields (Vrain et al., 1981). Soil fumigation with 1,3dichloropropene nematicide at the high rate of 300 liters $\cdot \mathrm{ha}^{-1}$ is the standard chemical treatment used for nematode control. The low efficacy and high cost of soil fumigation in organic soil, the pressure of environmental concerns, and the threat of possible withdrawal from the market of the remaining fumigant nematicides have created a sense of urgency in the search of alternative nematode management tactics.

Received for publication 9 Dec. 1994. Accepted for publication 19 Oct. 1995. Agriculture and Agrifood Canada contribution no. 335/95.11.01R. We thank Yvon Fournier for technical assistance. This study was supported by research grant no. 2619 from Conseil des Recherches en Pêche et en Agroalimentaire du Québec. The cost of publishing this paper was defrayed in part by the payment of page charges. Under postal regulations, this paper therefore must be hereby marked advertisement solely to indicate this fact.

${ }^{1}$ Nematologist.

${ }^{2}$ Professor.
Crop rotation has been recommended for reducing nematode populations and limiting crop damage in many cropping systems (McSorley et al., 1994; Nusbaum and Ferris, 1973; Raymundo, 1985). In the carrot production system, introducing small grains, nonhost crops to $M$. hapla, has provided large increases in marketable carrots (Bélair, 1992; Brzeski and Bodja, 1974; Wilson, 1962). Under small microplot conditions, the cropping sequence, onion-small grain-carrot, reduced $M$. hapla population densities below the detectable level and provided a $282 \%$ increase in marketable yield compared to the yield obtained in monoculture plots (Bélair, 1992). This cropping sequence has good potential for managing root-knot nematode in organic soils, but a more extensive evaluation or a field validation of this cropping sequence was required before it could be recommended to growers.

Our objective was to assess the influence of various cropping sequences, including an onion-barley-carrot sequence, on $M$. hapla population densities and carrot yields under field conditions.

\section{Materials and Methods}

The trial was conducted at Sherington, Quebec, Canada, in a 1.2-ha commercial carrot field on organic soil with a severe root-knot nematode problem. This peaty soil had a $80 \%$ to $85 \%$ organic content with a $\mathrm{pH}$ of 5.5. Plots $(15 \times 11 \mathrm{~m})$ were arranged in a randomized complete-block design with six replications. Crops included in the sequences were 'Sixpak' carrot $(\mathrm{C})$, 'Flame' onion (O), weedy fallow (F), and 'Birka' barley (B). Three-year cropping sequences of $\mathrm{C}-\mathrm{O}-\mathrm{C}, \mathrm{B}-\mathrm{C}-\mathrm{C}, \mathrm{F}-\mathrm{F}-\mathrm{C}$, $\mathrm{C}-\mathrm{B}-\mathrm{C}, \mathrm{B}-\mathrm{O}-\mathrm{C}, \mathrm{O}-\mathrm{B}-\mathrm{C}$, and $\mathrm{C}-\mathrm{C}-\mathrm{C}$ were investigated from 1989 to 1991 . Each experimental plot was surrounded by a 3-m band of barley that was mowed regularly during the growing season. Cultural practices were conducted according to Quebec's agricultural recommendations for each crop (Ministère de l'Agriculture, des Pêcheries et de l'Alimentation du Québec, 1987). In 1991, all plots were planted to carrot. At harvest, carrots were removed from four rows ( $1 \mathrm{~m}$ long) from each plot, graded for marketability, weighed, and rated on a root-gall index as follows: $0=$ no galling, no forking, no stunting, marketable; $1=$ one to 10 galls on secondary roots, taproot not affected, marketable; $2=11$ to 50 galls, none coalesced, taproots with light forking, no stunting, unmarketable; $3=51$ to 100 galls with some coalesced, forking, no stunting, unmarketable; $4=$ more than 100 galls with some coalesced, severe forking and moderate stunting, unmarketable; $5=$ more than 100 galls, mostly coalesced, severe stunting, unmarketable (Fig. 1). Based on this root-gall index, an economic threshold of $0.65(60 \%$ marketable roots) has been established on the average production return and soil fumigation costs in muck-grown carrots (Bélair and Boivin, 1988). Soil samples for nematode as-
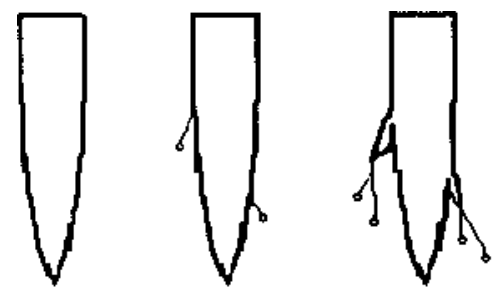

O

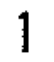

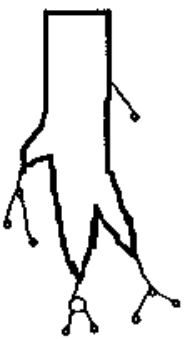

3

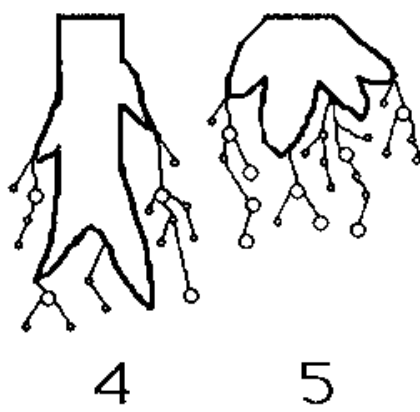

Fig. 1. Root-knot nematode galling and nematode damage index (on a scale from 0 to 5): $0=$ no galling, no forking, no stunting, marketable; $1=$ one to 10 galls on secondary roots, taproot not affected, marketable; $2=11$ to 50 galls, none coalesced, taproots with light forking, no stunting, marketable; $3=51$ to 100 galls with some coalesced, forking, no stunting, unmarketable; $4=$ more than 100 galls with many coalesced, severe forking, moderate stunting, unmarketable; $5=$ more than 100 galls, mostly coalesced, severe stunting, unmarketable. 
says were collected each year before planting and after harvest. Each sample consisted of eight to 10 soil cores $(5 \mathrm{~cm}$ in diameter $\times 20 \mathrm{~cm}$ deep) collected randomly on each row. Meloidogyne hapla second-stage juvenile (J2) population densities in each plot were assayed by processing a $100-\mathrm{cm}^{3}$ soil subsample using a modified Baermann pan method (Townshend, 1963).

Nematode counts were transformed using $\log _{10}(x+1)$ before statistical analysis. Data were analyzed by general linear model procedures (SAS institute, Cary, N.C.). WallerDuncan k-ratio $t$ test was used to compare treatments when analysis of variance showed significant differences among means.

\section{Results}

In 1989, when the experiment was established, J2 preplant densities ranged from 5 to $360 / 100 \mathrm{~cm}^{3}$ soil, with no significant differences among treatments (Table 1). At harvest, $\mathrm{J} 2$ densities were significantly higher in carrot plots than in all other crops.

In 1990, J2 preplant densities were high in plots previously planted with carrot and plots that were weedy fallow; densities were low in all other treatments (Table 1). At harvest, J2 densities were low in all plots except those in weedy fallow and carrot monoculture. In the $\mathrm{B}-\mathrm{C}-\mathrm{C}$ and $\mathrm{C}-\mathrm{C}-\mathrm{C}$ sequences, carrot yields were recorded as previously mentioned and were estimated at $88 \%\left(55 \mathrm{t}^{\circ} \cdot \mathrm{ha}^{-1}\right)$ and $8 \%$ (4 t.ha $\left.{ }^{-1}\right)$ marketable roots, respectively.

In 1991, the J2 preplant densities were significantly lower following $\mathrm{O}-\mathrm{B}, \mathrm{B}-\mathrm{O}$, and $\mathrm{C}-\mathrm{B}$ cropping sequences than all other treatments (Table 1). At harvest, $\mathrm{J} 2$ densities were significantly lower following $\mathrm{O}-\mathrm{B}-\mathrm{C}, \mathrm{B}-\mathrm{O}-$ $\mathrm{C}$, and $\mathrm{C}-\mathrm{B}-\mathrm{C}$ than in the other cropping sequences. The percentage of marketable carrots was above the economic threshold in the $\mathrm{O}-\mathrm{B}-\mathrm{C}, \mathrm{B}-\mathrm{O}-\mathrm{C}$, and $\mathrm{C}-\mathrm{B}-\mathrm{C}$ cropping sequences (Table 2). The highest weights of marketable carrots were recorded in the $\mathrm{B}-\mathrm{O}$ $\mathrm{C}$ and $\mathrm{O}-\mathrm{B}-\mathrm{C}$ cropping sequences, with yields of marketable carrots more than 20 times that for the carrot monoculture, where yield was the lowest. The root-gall index of carrots was high following $\mathrm{F}-\mathrm{F}-\mathrm{C}$ and $\mathrm{C}-\mathrm{C}-\mathrm{C}$; intermediate after $\mathrm{C}-\mathrm{O}-\mathrm{C}, \mathrm{B}-\mathrm{C}-\mathrm{C}$, and $\mathrm{C}-\mathrm{B}-\mathrm{C}$; and low after $\mathrm{B}-\mathrm{O}-\mathrm{C}$ and $\mathrm{O}-\mathrm{B}-\mathrm{C}$ cropping sequences.

Table 1. Effect of cropping sequences on Meloidogyne hapla population densities under large field-plot conditions in organic soil.

\begin{tabular}{|c|c|c|c|c|c|c|}
\hline \multirow{3}{*}{$\begin{array}{l}\text { Cropping } \\
\text { sequence } \\
\text { 1989-90-91 }\end{array}$} & \multicolumn{6}{|c|}{ No. M. hapla second-stage larvae $/ 100 \mathrm{~cm}^{3}$ soil ${ }^{2}$} \\
\hline & \multicolumn{2}{|c|}{1989} & \multicolumn{2}{|c|}{1990} & \multicolumn{2}{|c|}{1991} \\
\hline & Preplant & Harvest & Preplant & Harvest & Preplant & Harvest \\
\hline $\mathrm{O}-\mathrm{B}-\mathrm{C}^{\mathrm{y}}$ & $46 \mathrm{a}$ & $31 \mathrm{~b}$ & $39 \mathrm{~b}$ & $0 \mathrm{~b}$ & $17 \mathrm{~b}$ & $1 \mathrm{c}$ \\
\hline $\mathrm{B}-\mathrm{O}-\mathrm{C}$ & $40 \mathrm{a}$ & $15 \mathrm{~b}$ & $3 \mathrm{~b}$ & $1 \mathrm{~b}$ & $0 \mathrm{~b}$ & $1 \mathrm{c}$ \\
\hline $\mathrm{C}-\mathrm{B}-\mathrm{C}$ & $35 \mathrm{a}$ & $1236 \mathrm{a}$ & $232 \mathrm{a}$ & $3 \mathrm{~b}$ & $0 \mathrm{~b}$ & $4 \mathrm{c}$ \\
\hline $\mathrm{B}-\mathrm{C}-\mathrm{C}$ & $13 \mathrm{a}$ & $3 \mathrm{~b}$ & $1 \mathrm{~b}$ & $4 \mathrm{~b}$ & $121 \mathrm{a}$ & $245 \mathrm{a}$ \\
\hline $\mathrm{C}-\mathrm{O}-\mathrm{C}$ & $9 \mathrm{a}$ & $1206 \mathrm{a}$ & $265 \mathrm{a}$ & $33 \mathrm{~b}$ & $52 \mathrm{a}$ & $81 \mathrm{~b}$ \\
\hline $\mathrm{F}-\mathrm{F}-\mathrm{C}$ & $98 \mathrm{a}$ & $55 \mathrm{~b}$ & 329 a & $335 \mathrm{a}$ & $242 \mathrm{a}$ & $320 \mathrm{a}$ \\
\hline $\mathrm{C}-\mathrm{C}-\mathrm{C}$ & $46 \mathrm{a}$ & $1601 \mathrm{a}$ & $331 \mathrm{a}$ & 1458 a & $140 \mathrm{a}$ & $89 \mathrm{~b}$ \\
\hline
\end{tabular}

${ }^{2}$ Means followed by different letters in columns are different at $P \leq 0.05$ according to the Waller-Duncan k-ratio $t$ test.

${ }^{\mathrm{y}} \mathrm{C}=$ carrot, $\mathrm{F}=$ weedy fallow, $\mathrm{O}=$ onion, $\mathrm{B}=$ barley.
The $\mathrm{B}-\mathrm{O}$ and $\mathrm{O}-\mathrm{B}$ cropping sequences were the most effective in reducing $M$. hapla population densities and providing profitable carrot yield increases the subsequent year unces at harvest, carrot could be grown economically for a second year following both sequences. These results confirm earlier observations in small microplots in southwestern Quebec (Bélair, 1992). In terms of monetary returns, the $\mathrm{B}-\mathrm{O}$ and $\mathrm{O}-\mathrm{B}$ sequences provide a profit (in Canadian dollars) of $\$ 2200 /$ ha over the 3-year sequence (Ministère de l'Agriculture, des Pêcheries et de l'Alimentation, 1990). For all other sequences, the net losses range from (in Canadian dollars) $\$ 1294$ to $\$ 6779 /$ ha. For economic reasons, growers cannot extend the number of years in rotation without their primary crop (carrot) for more than 2 years. An integrated pest management (IPM) program to manage M. hapla is being used by carrot growers in Quebec based on an assessment of nematode damage potential (root damage indices) obtained from the previous carrot crop (Bélair and Boivin, 1988). The program provides for a mapping of the nematode distribution in each field and optimizes $M$. hapla management decisions by subdividing the field and practicing a rotation only in the areas where the nematodes are located.

A single year of barley, a resistant crop, significantly reduced $M$. hapla population densities near or below the detectable level but provided only a single profitable carrot crop in the $\mathrm{B}-\mathrm{C}-\mathrm{C}$ and $\mathrm{C}-\mathrm{B}-\mathrm{C}$ cropping sequences. Thus, under a severe nematode infestation, a single crop of small grain would not be an economically viable alternative in carrot production. A good preventive practice, however, would be to introduce a small grain as a rotating crop in all carrot fields every 3 to 5 years to reduce the potential of nematode infestation and thus provide long-term management of $M$. hapla. The introduction of a small grain in the cropping system also would be economically justifiable by its other positive effects, such as increasing the soil fiber content and, thus, reducing loss from wind erosion. Using a small grain would improve weed control via efficacious herbicides against specific weed problems that cannot be managed in carrot and der field conditions. Based on root-gall indi-
Table 2. Effect of cropping sequences on carrot yields in the last year of the cropping sequence under large field-plot conditions in organic soil.

\begin{tabular}{|c|c|c|c|}
\hline $\begin{array}{l}\text { Cropping } \\
\text { sequences }\end{array}$ & \multicolumn{2}{|c|}{$\begin{array}{c}\text { Marketable } \\
\text { roots }^{\mathrm{z}}\end{array}$} & $\begin{array}{l}\text { Root- } \\
\text { gall }\end{array}$ \\
\hline $1989-90-91^{\mathrm{y}}$ & $\%$ & $\mathrm{t} \cdot \mathrm{ha}^{-1}$ & index \\
\hline B-O-C & $88.9 \mathrm{a}$ & $56.8 \mathrm{a}$ & $0.1 \mathrm{e}$ \\
\hline $\mathrm{O}-\mathrm{B}-\mathrm{C}$ & $83.4 \mathrm{ab}$ & $47.4 \mathrm{~b}$ & $0.1 \mathrm{e}$ \\
\hline $\mathrm{C}-\mathrm{B}-\mathrm{C}$ & $72.6 \mathrm{bc}$ & $34.0 \mathrm{c}$ & $0.4 \mathrm{de}$ \\
\hline $\mathrm{B}-\mathrm{C}-\mathrm{C}$ & $64.5 \mathrm{c}$ & $33.1 \mathrm{c}$ & $0.8 \mathrm{~cd}$ \\
\hline $\mathrm{C}-\mathrm{O}-\mathrm{C}$ & $49.1 \mathrm{~d}$ & $23.0 \mathrm{~d}$ & $1.2 \mathrm{c}$ \\
\hline $\mathrm{F}-\mathrm{F}-\mathrm{C}$ & $45.5 \mathrm{~d}$ & $15.3 \mathrm{e}$ & $1.8 \mathrm{~b}$ \\
\hline $\mathrm{C}-\mathrm{C}-\mathrm{C}$ & $7.3 \mathrm{e}$ & $2.2 \mathrm{f}$ & $3.5 \mathrm{a}$ \\
\hline
\end{tabular}

${ }^{\mathrm{z}}$ Means followed by different letters in columns are different at $P \leq 0.05$ according to the WallerDuncan k-ratio $t$ test.

${ }^{\mathrm{y}} \mathrm{C}=$ carrot, $\mathrm{F}=$ weedy fallow, $\mathrm{O}=$ onion, $\mathrm{B}=$ barley.

onion production (D.L. Benoit, personal communication).

Onion is an intermediate host of M. hapla and reduces populations of this nematode when compared to carrot (Bélair, 1992; Brzreski and Bodja, 1974; Kotcon et al., 1985; Wilson, 1962). In our study, a single crop of onion did not provide a useful level of root-knot nematode control in carrot production. The efficiency of onion could have been lessened by the presence of many common weeds, such as oak-leaved goosefoot (Chenopodium glaucum L.), green smartweed (Polygonum scabrum Moench), and marsh yellow cress [Rorippa islandica (Oeder) Borb.] (Leroux et al., 1996). These weeds have been good hosts of M. hapla in organic soil (unpublished observations). High M. hapla population densities and the high level of culls recorded in weedy fallow plots also emphasize the importance of an effective weed management program for the successful use of crop rotation.

Our study demonstrated that $\mathrm{B}-\mathrm{O}$ and $\mathrm{O}-$ $B$ cropping sequences are efficacious and costeffective rotations for managing $M$. hapla in carrot production. These results may contribute to the introduction of such control practices in the IPM program and, thus, reduce the dependence on nematicides in the carrot cropping system of southwestern Quebec.

\section{Literature Cited}

Bélair, G. 1992. Effects of cropping sequences on population densities of Meloidogyne hapla and carrot yield in organic soil. J. Nematol. 24:450456.

Bélair, G. and G. Boivin. 1988. Spatial pattern and sequential sampling plan for Meloidogyne hapla in muck-grown carrots. Phytopathology 78:604607.

Berney, M.F. and G.W. Bird. 1992. Distribution of Heterodera carotae and Meloidogyne hapla in Michigan carrot production. J. Nematol. 24:776778.

Brzeski, M.W. and Z. Bodja. 1974. The northern root-knot nematode (Meloidogyne hapla Chitwood) on carrot-Pathogenicity and control (in Polish, English summary). Zeszyty Problemowe Postepow Nauk Rolniczych 154:159-172.

Comité de Références Économiques en Agriculture du Québec. 1990. Références économiques en agriculture. Ministère de l'Agriculture, des Pêcheries et de l'Alimentation du Québec, Agdex 250/821, Québec, Canada. 
Kotcon, J.B., G.W. Bird, L.M. Rose, and K. Dimoff. 1985. Influence of Glomus fasciculatum and Meloidogyne hapla on Allium cepa in organic soils. J. Nematol. 17:55-60.

Leroux, G.D., D.L. Benoit, and S. Banville. 1996. Effect of crop rotations on weed control, Bidens cernua and Erigeron canadensis populations, and carrot yields in organic soils. Crop Protection (In press.)

McSorley, R., D.W. Dickson, J.A. De Brito, and R.C. Hochmuth. 1994. Tropical rotation crops influence nematode densities and vegetable yields. J. Nematol. 26:308-314.

Ministère de l'Agriculture, des Pêcheries et de l'Alimentation. 1987. Légumes-Protection.
Conseil des Productions Végétales du Québec. Ministère de l'Agriculture, des Pêcheries et de l'Alimentation, Québec, Canada.

Nusbaum, C.J. and H. Ferris. 1973. The role of cropping systems in nematode population management. Annu. Rev. Phytopathol. 11:423-440.

Raymundo, S.A. 1985. Cropping systems research and root-knot nematode control, p. 277-281. In: J.N. Sasser and C.C. Carter (eds.). An advanced treatise on Meloidogyne. vol. 1. Biology and control. North Carolina State Univ. Graphics, Raleigh.

Townshend, J.L. 1963. A modification and evaluation of the apparatus for the Oostenbrink direct cotton-wool filter extraction method.
Nematologica 9:106-110.

Vrain, T.C. 1978. Dissémination et importance des nématodes phytoparasites dans les sols organiques du Québec. Phytoprotection 59:186. (Abstr.)

Vrain,T.C. 1982. Relationship between Meloidogyne hapla density and damage to carrots in organic soils. J. Nematol. 14:50-57.

Vrain, T.C., Y. Fournier, and R. Crête. 1981. Carrot yield increases after chemical control of rootknot nemaotde in organic soil. Can. J. Plant Sci. 61:677-682.

Wilson, J.D. 1962. Crop rotation and the control of root-knot on muck grown vegetables. Phytopathology 52:33. (Abstr.) 